\title{
Bioactive compounds in the peel of camu camu genotypes from Embrapa's active germplasm bank
}

\author{
Aline SOUZA ${ }^{1}$, Thaise OLIVEIRA ${ }^{1}$, Rafaella MATTIETTO ${ }^{2}$, Walnice NASCIMENTO ${ }^{2}$, Alessandra LOPES ${ }^{1 *}$
}

\begin{abstract}
Our objective in this work was to evaluate the contents of the major bioactive compounds in the peel of three genotypes of camu camu at different maturity stages. The genotypes had high concentration of ascorbic acid in the peel ranging from $13.73 \%$ to $24.02 \%$. In the ripe maturity stage the genotypes 17 and 44 presented the highest concentration of phenolics $\left(3,299.97 \mathrm{mg} \mathrm{GAE} .100 \mathrm{~g} \mathrm{~g}^{-1}\right)$ and anthocyanins $\left(165.91 \mathrm{~g} .100 \mathrm{~g} \mathrm{~g}^{-1}\right)$. Flavonols and carotenoids showed a distinct and statistically

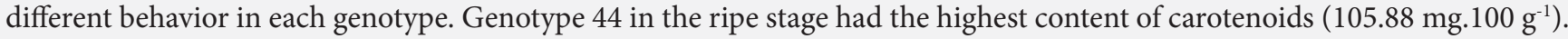
The high contents of vitamin $\mathrm{C}$ and phenolic compounds make the residue of camu camu fruit processing a rich source of antioxidants to the food and/or pharmaceutical industries.
\end{abstract}

Keywords: antioxidants; maturity; phytochemicals; residue; vitamins.

Practical Application: Production of the antioxidant extracts for use as food ingredient and/or drugs.

\section{Introduction}

Camu-camu (Myrciaria dubia (HBK) McVaugh), belonging to the family Myrtaceae, is a bush native to the Amazon rainforest with round berries averaging $2.5 \mathrm{~cm}$ in diameter. This fruit has high antioxidant capacity because of its high vitamin $\mathrm{C}$ $\left(2,280 \mathrm{mg} 100 \mathrm{~g} \mathrm{~g}^{-1}\right)$ and total phenolic (1,420 mg GAE $\left.100 \mathrm{~g}^{-1}\right)$ content. The pulp of camu camu is exported mainly to Japan, Europe, and the USA (Zanatta et al., 2005; Chirinos et al., 2010; Yuyama, 2011).

A study carried out by Chirinos et al. (2010) found the presence of 30 different phenolic compounds in the camu camu fruit, especially flavan-3-ols, ellagic acid, and its derivates, flavonols and flavanones. Besides polyphenols, camu camu also has carotenoids, mainly trans-lutein and $\beta$-carotene (Azevedo-Meleiro \& Rodriguez-Amaya, 2004; Zanatta \& Mercadante, 2007).

The bioactive compounds in camu camu can vary according to the fruit's maturity stage, detected through the peel color, which changes during the ripening process from green to shades of red and purple (Zanatta \& Mercadante, 2007), with an increase in the contents of ascorbic acid and anthocyanins (Villanueva-Tiburcio et al., 2010).

Bioactive compounds exert a powerful biologic activity and play several roles in benefiting human health. They are, on average, secondary metabolites related with the plant defense system against ultraviolet radiation and aggressions from insects and pathogens (Manach et al., 2004), and with the biosynthesis of substances that signal pollination (Rice-Evans et al., 1996). These naturally occurring phytochemicals are complex mixtures that differ among plants, plant parts, and development stages (Wink, 2004).

The goal of this study is to quantify and correlate the main bioactive compounds and the in vitro antioxidant capacity of camu camu peel as a function of the maturity stage in fruits of three different genotypes.

\section{Materials and methods}

The camu camu fruit samples were collected from different mother plants from the Germoplasm Bank of Embrapa Eastern Amazon, located in Belém, state of Pará, Brazil ( $\left.1^{\circ} 28^{\prime} \mathrm{S}, 48^{\circ} 29^{\prime} \mathrm{W}\right)$. The genotypes named 17, 38 and 44 were chosen by its high productivity and plague resistance. Fruits of three genotypes were randomly chosen at three maturity stages according to the to the color characteristics of the peel: green (90 to 100\% green), semi-ripe (10 to $80 \%$ red), and ripe (above $80 \%$ red), according described in Table 1 . The whole fruits were selected, hygienized, and manually depulped to separate the pulp, peel, and seed. The peel was homogenized, placed in laminated plastic vacuum packages, and stored at freezing temperature $\left(-20^{\circ} \mathrm{C}\right)$ until the analyses were performed.

\subsection{Ascorbic acid}

AOAC method 43.065 (Association of Official Analytical Chemists, 1984), based on the reduction of 2,6-dichlorophenolindophenol sodium (DCFI) by ascorbic acid. The results were expressed as $\mathrm{g} 100 \mathrm{~g}^{-1}$ of peel. 
Table 1. Bioactive compound contents (in dry basis) in camu camu peel as a function of maturity in different genotypes.

\begin{tabular}{|c|c|c|c|c|c|c|}
\hline Genotypes & Maturity stage & $\begin{array}{l}\text { Ascorbic acid } \\
\left(\mathrm{g} 100 \mathrm{~g}^{-1}\right)\end{array}$ & $\begin{array}{l}\text { Total phenolics } \\
\left(\mathrm{mg} \text { GAE } 100 \mathrm{~g}^{-1}\right)\end{array}$ & 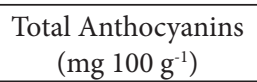 & $\begin{array}{l}\text { Flavonols } \\
\left(\mathrm{mg} \mathrm{QE} \mathrm{g}^{-1}\right)\end{array}$ & $\begin{array}{l}\text { Total Carotenoids } \\
\quad\left(\mathrm{mg} \mathrm{100} \mathrm{g}^{-1}\right)\end{array}$ \\
\hline 17 & Semi-ripe & $15.37 \pm 0.06^{\mathrm{e}}$ & $1,213.02 \pm 51.72^{\mathrm{c}}$ & $35.34 \pm 0.01^{\mathrm{d}}$ & $184.27 \pm 6.7^{\mathrm{e}}$ & $73.72 \pm 0.08^{e}$ \\
\hline \multirow[t]{2}{*}{38} & Green & $16.09 \pm 0.05^{\mathrm{e}}$ & $1,220.71 \pm 0.31^{\mathrm{c}}$ & nd & $184.93 \pm 3.27^{\mathrm{e}}$ & $92.72 \pm 0.09^{c}$ \\
\hline & Semi-ripe & $13.73 \pm 0.07^{\mathrm{f}}$ & $1,576.52 \pm 241.17^{b}$ & $21.58 \pm 0.01^{\mathrm{f}}$ & $166.64 \pm 3.30^{\mathrm{f}}$ & $44.35 \pm 0.18^{\mathrm{h}}$ \\
\hline \multirow{2}{*}{44} & Semi-ripe & $17.06 \pm 0.09^{\mathrm{d}}$ & $797.6 \pm 179.98^{e}$ & $25.24 \pm 0.02^{\mathrm{e}}$ & $228.66 \pm 4.65^{c}$ & $98.48 \pm 0.23^{\mathrm{b}}$ \\
\hline & Ripe & $24.02 \pm 0.18^{\mathrm{a}}$ & $881.46 \pm 88.68^{\mathrm{e}}$ & $165.91 \pm 0.39^{\mathrm{a}}$ & $142.15 \pm 7.24^{\mathrm{g}}$ & $105.88 \pm 0.25^{\mathrm{a}}$ \\
\hline
\end{tabular}

Values are means of triplicate determinations $(n=3) \pm$ standard deviation. Different letters in the same column are significantly different $(p \leq 0.05)$. nd: not detected.

\subsection{Total carotenoids}

The total carotenoids was carried out using the method described by Rodriguez (2001). The assay used $5 \mathrm{~g}$ of sample at each maturity stage and petroleum ether as extraction solvent, with results expressed as a function of $\beta$-carotene, absorbance peak at $450 \mathrm{~nm}$, and absorption coefficient of $2,592 \mathrm{~A}_{1 \mathrm{~cm}}{ }^{1 \%}$. The results were expressed as $\mathrm{mg} 100 \mathrm{~g}^{-1}$ of peel.

\subsection{Total phenolics}

The total phenolics was carried out using the Folin-Ciocalteu method described by Singleton \& Rossi (1965) and modified by Georgé et al. (2005), in which 1 to $3 \mathrm{~g}$ of the sample at each maturity stage were used. To remove interfering substances, the raw extract (obtained from the dilution of the sample in $70 \%$ acetone and then filtration) was washed twice in Oasis HLB $6 \mathrm{cc}$ cartridges (Waters ${ }^{\circledR}$ ) with distilled water. The polyphenol content was calculated based on the standard curve of gallic acid, measured through the difference between the raw extract (interfering substances and polyphenols) and the washed extract (interfering substances). Absorbance was read at $760 \mathrm{~nm}$ and the results were expressed as GAE (gallic acid equivalent) as $\mathrm{mg} 100 \mathrm{~g}^{-1}$ of peel.

\subsection{Total anthocyanins}

Total anthocyanins were quantified according to the single pH spectrophotometric method as described by Fuleki \& Francis (1968) and revised by Lees \& Francis (1972). For the sample of the ripe and semi-ripe stages, 2 and $3 \mathrm{~g}$ of sample were used, respectively. For anthocyanin extraction, a 95\% ethanol solution was used: $\mathrm{HCl} 1.5 \mathrm{~N}(85: 15, \mathrm{v} / \mathrm{v})$. After the extraction step, the reading was carried out in a UV-visible spectrophotometer (Thermo Scientific, Evolution 60) with $535 \mathrm{~nm}$ wavelength. The results were expressed as $\mathrm{mg} 100 \mathrm{~g}^{-1}$ of peel.

\subsection{Flavonols}

The aluminum chloride reaction method was used to quantify the flavonols and flavones family, as described by Meda et al. (2005) The results were calculated based on the calibration curve built with quercertin and expressed as $\mathrm{mg}$ of quercertin equivalent $(\mathrm{QE})$ per $\mathrm{g}$ of peel $\left(\mathrm{mg} \mathrm{QE}^{-1}\right)$.

\subsection{Antioxidant capacity}

\section{$D P P H^{*}$ assay}

The DPPH $\cdot$ assay was assessed using the method of Brand-Williams et al. (1995). The antioxidant capacity was expressed as the concentration of extract necessary to decrease the initial concentration of $\mathrm{DPPH}^{*}$ by $50 \%$ (EC50) under the specified experimental condition and values expressed as g peel g DPPH:

\section{ABTS+ assay}

The ABTS+ assay was carried out according to the methodology proposed by Rufino et al. (2010), which measures the reduction in the concentration of the radical ABTS [2,2-azino-bis (3-ethylbenzothiazoline)-6-sulfonic acid] captured by the sample's antioxidants tested and by the water-soluble equivalent of vitamin $\mathrm{E}$. The extract was prepared from $1 \mathrm{~g}$ of sample, using as solvent $50 \%$ methanol, $70 \%$ acetone, and distilled water, which was homogenized, centrifuged (11,000 rpm for $15 \mathrm{~min}$ ) and filtered in two steps.

The samples were analyzed in triplicate after the $2 \mathrm{mM}$ trolox standard was prepared and read at different dilutions to obtain the standard curve. The reading was performed in a spectrophotometer at $734 \mathrm{~nm}$ after 6 min of mixing the ABTS extract with the sample extract at different dilutions using ethyl alcohol as blank. The result was expressed in $\mu \mathrm{M}$ trolox g ${ }^{-1}$ of peel.

\subsection{Statistical analysis}

The results were analyzed through analysis of variance (ANOVA) and Tukey's mean comparison test with a 95\% confidence interval, using the software Statistica ${ }^{\circledR}$ version 7.0 (Statsoft Inc., 2004), to compare the statistical differences among the maturity stages and the genotypes studied. Pearson's correlation coefficient $(\mathrm{R})$ was used to assess the intensity of the linear association between the bioactive compounds and antioxidant capacity of the three different genotypes.

\section{Results and discussion}

In the present study, genotypes 38 and 44 had an increase in ascorbic acid content, comparing the green and ripe stages, while genotype 17 had a decrease during maturation, with no 
statistical difference between the semi-ripe and ripe stages (Table 1). Genotype 44 was the one that had the highest ascorbic

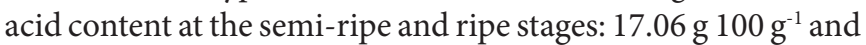

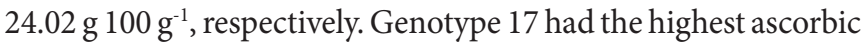

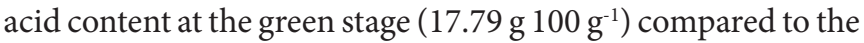
other genotypes at the same maturity stage.

Villanueva-Tiburcio et al. (2010) observed a reduction in ascorbic acid content during maturation in the vitamin $\mathrm{C}$ content in the peel of fresh camu camu fruits from the region of Ucayali, Peru. According Chirinos et al. (2010) the ascorbic acid content was higher in green maturity stage $(2,280 \mathrm{mg}$ ascorbic acid $100 \mathrm{~g}^{-1}$ fruit), but at full maturity the value of 2,010 mg ascorbic acid $100 \mathrm{~g}^{-1}$ fruit presented $11.8 \%$ lower than in green stage.

In contrast, Alves et al. (2002) and Yuyama (2011) have reported increases in ascorbic acid during the maturation and ripening of the camu-camu fruit.

According Justi et al. (2000) differences in environmental conditions (e.g., soil and climatic variations) can also affect the vitamin C content of camu-camu fruit and Correa et al. (2011) related that the ascorbic acid content in camu-camu fruit decreases with the maturity stage because of the action of enzymes such as ascorbate oxidase, phenolase, and cytochrome oxidase.

Regardless of the maturity stage, the vitamin $\mathrm{C}$ content found in camu camu peel is very high compared to other tropical fruits (Assunção \& Mercadante, 2003; Matta et al., 2004; Rufino et al., 2010; Almeida et al., 2011; Yazawa et al., 2011), and shows the potential use of this part of the fruit for applications in the cosmetic, pharmaceutical, and supplement industries, among others.

Total phenolic content increased in all genotypes during maturation, but genotype 17 had a much higher increase compared with the others at the ripe stage $\left(3,298.98 \mathrm{mg}\right.$ GAE $\left.100 \mathrm{~g}^{-1}\right)$. Genotype 44 had the lowest total phenolic content at all maturity stages, with no statistical difference between the semi-ripe and ripe stages (Table 1 ).

In the study by Villanueva-Tiburcio et al. (2010), the highest total phenolic content was found in semi-ripe camu camu peel (77.0 mg GAE $100 \mathrm{~g}^{-1}$ ). According Chirinos et al. (2010) total phenolic contents in edible portion (peel and flesh) of camu camu increased from the full green to green-reddish stage and then decreased by seven percent at the red stage.

Reynertson et al. (2008) analyzed the phenolic compounds and antioxidant activity in 14 fruits of the Myrtaceae family and found that Myrciaria dubia had the higher total phenolic content (1,010 mg GAE $\left.100 \mathrm{~g}^{-1}\right)$ and flavonols levels of approximately six times higher (24 mg $\left.100 \mathrm{~g}^{-1}\right)$ than the other fruits investigated.

The anthocyanin content increased during ripening for all genotypes. No results were found for the green stage due to the low amount of anthocyanins at this stage. When semi-ripe,

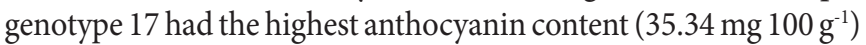
compared with the others, while at the ripe stage genotype 44 stood out $\left(165.91 \mathrm{mg} 100 \mathrm{~g}^{-1}\right)$. No statistical difference was found between genotypes 17 and 38 at the ripe stage (Table 1).
Villanueva-Tiburcio et al. (2010) found an increase in peel anthocyanin content in fresh camu camu fruits compared with the semi-ripe and ripe stages, with values of 3.83 and $46.43 \mathrm{mg} 100 \mathrm{~g}^{-1}$, respectively.

Zanatta et al. (2005) found total anthocyanin values

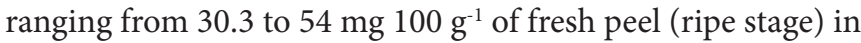
two regions of the state of São Paulo. This shows that the peel of camu camu fruit can be considered a potential source of anthocyanins, especially cyanidin-3-glucoside (89\%) followed by delphinidin-3-glucoside (5\%).

Genotype 17 had a reduction in flavonols between the green and semi-ripe stages and an increase in the ripe stage, genotype 38 had a reduction during maturation, while genotype 44 had no statistically different variation between the green and semi-ripe stages, but a decrease at the ripe stage (Table 1). The highest flavonol content was found for genotype 17 at the green stage (343.63 mg QE $100 \mathrm{~g}^{-1}$ ) and the lowest was found for genotype

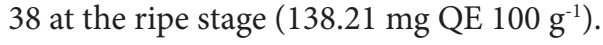

Contents in acerola, for instance, range from 175 to $625 \mu \mathrm{g} \mathrm{QE} \mathrm{g}^{-1}$ of edible part (dry basis) (Huber \& Rodriguez-Amaya, 2008).

Rutz et al. (2012) investigated some bioactive compounds of blackberry (Rubus spp.) at different maturity stages and they found the complete loss in quercertin content during maturation.

Jaakola et al. (2002) had also observed in bilberry fruits a reduction in quercetin concentration during the maturation. These authors showed a correlation between anthocyanin synthesis and the expression of the flavonoid pathway genes of berries. Procyanidins and quercetin were the major flavonoids in green fruits, however the concentration of these compounds decreased significantly during the progress of ripening.

Table 1 shows the relationship between carotenoid content and maturity, which is different for every genotype. Genotype 17 had a slight decrease during maturation with no statistical difference between the semi-ripe and ripe stages; genotype 38 had a significant decrease in carotenoid content between the green and semi-ripe stages and an increase in the ripe stage, while genotype 44 had an increase throughout maturation. The highest carotenoid content was found in genotype 44 at the ripe stage, while the lowest was found in genotype 38 in the semi-ripe stage.

It is common to observe in plants differences in carotenoid accumulation between tissues and cultivars. Fu et al. (2014) showed that the differential expression of carotenogenic genes was unsatisfactory to justify the large difference in carotenoid content between cultivars of loquat, indicating that there may be another regulatory mechanism underlying this phenomenon.

According to Rufino et al. (2010), camu camu pulp has mean carotenoid contents $\left(1.32 \mathrm{mg} 100 \mathrm{~g}^{-1}\right)$ lower than those of acerola (5.19 mg $100 \mathrm{~g}^{-1}$ ), however, higher than jaboticaba

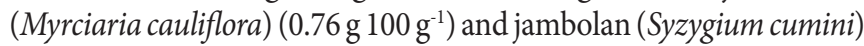

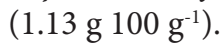

Genotypes $17\left(42.52,48.28\right.$, and 38.95 g peel g $\left.^{-1} \mathrm{DPPH}\right)$ and $44\left(65.07,41.03\right.$, and $53.78 \mathrm{~g}$ peel $\left.\mathrm{g}^{-1} \mathrm{DPPH}\right)$ had the highest antioxidant capacity through the DPPH method in comparison 
with genotype $38\left(91.75,53.35\right.$, and $54.15 \mathrm{~g}$ peel $\left.\mathrm{g}^{-1} \mathrm{DPPH}\right)$ at all maturity stages (Figure 1).

The highest antioxidant activity through the ABTS+ method was found in genotype 44 at the ripe stage $(1,701.63 \mu \mathrm{M}$ trolox $\left.\mathrm{g}^{-1}\right)$ and the lowest was found in genotype 38 at the green stage (911.44 $\mu \mathrm{M}$ trolox $\mathrm{g}^{-1}$ ) (Figure 2).

Rufino et al. (2010) showed that camu camu had the highest antioxidant activity compared with the other fruits analyzed, with $1,237.00 \mu \mathrm{M}$ trolox $\mathrm{g}^{-1}$ (wet basis) of antioxidant activity for its pulp and peel.

Pearson's correlation coefficient (R) was used to determine the intensity of the linear association between the bioactive compounds and antioxidant capacity during maturation and in the three different genotypes. In genotype 17, a positive correlation $(p \leq 0.05)$ was observed between ascorbic acid and flavonols content and ABTS+ at 0.95 and 0.99 , respectively. There was no linear correlation $(p>0.05)$ between phenolics and ABTS+ (-0.08) and DPPH (-0.30), because of the high content of ascorbic acid that is sixteen times higher than phenolics content. The results of ABTS+ and DPPH practically show only the ascorbic acid variation.

There is a non-linear relationship between the antioxidant concentration and the DPPH radical scavenging activity because of the different antioxidant mechanisms contribution in DPPH radical scavenging (Chen et al., 2013).

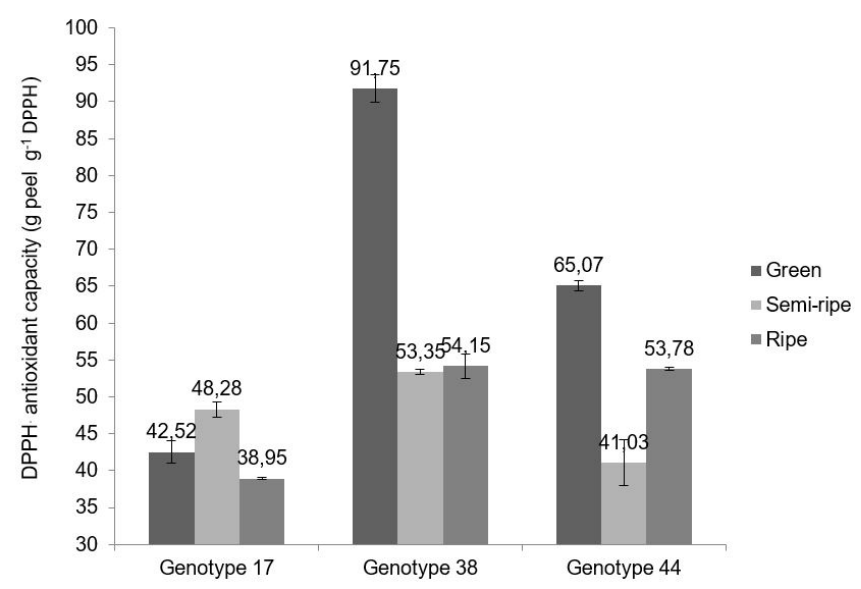

Figure 1. DPPH• scavenging capacity values of camu camu peel.

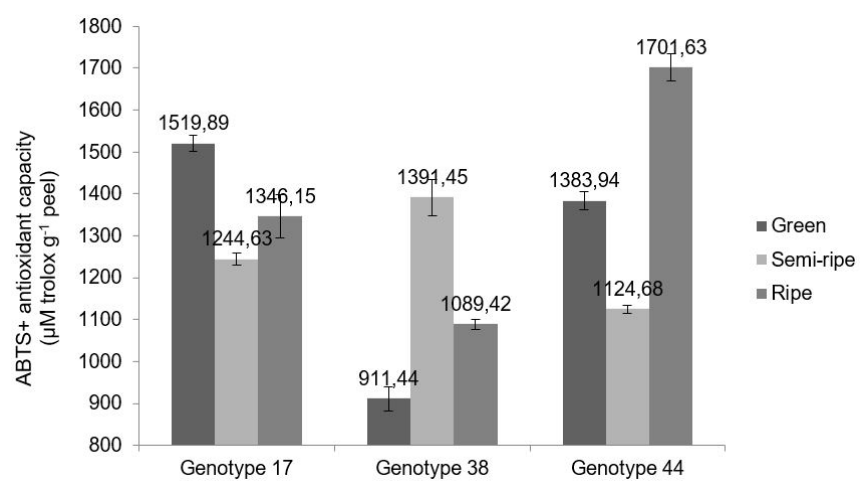

Figure 2. ABTS+ antioxidant capacity values of camu camu peel.
Delva \& Goodrich-Schneider (2013) found a high correlation between DPPH and ascorbic acid in acerola juices however this behavior was not found between DPPH and total phenolics.

For genotype 38, a negative linear correlation $(p \leq 0.05)$ was found between total phenolic content and DPPH (-0.97). The negative association in this case represents a directly proportional relation between the presence of these bioactive compounds and antioxidant activity since the result of the methodology through DPPH is expressed as $\mathrm{IC}^{50}$, i.e., the higher the antioxidant activity, the lowest its value in $\mathrm{IC}^{50}$.

Genotype 44 had a positive correlation between ascorbic acid and ABTS+ antioxidant activity with a value of $0.88(p \leq 0.05)$.

The interaction between the bioactive compounds and antioxidant activity in vitro is complex since it comprises several factors and substances present in the fruit, their inter-relations, and the different methodology employed in the analysis.

\section{Conclusion}

The high levels of ascorbic acid, phenolic compounds, and carotenoids found in camu camu peel combined with antioxidant capacity shows that this residue may represent a new source of functional compounds for the improvement of human nutrition. Clarifying the formation of bioactive compounds at different maturity stages and in different genotypes is important since it may provide information required for the pharmaceutical and/or functional food industries to optimize the extraction of these compounds, as well as help camu camu producers choose a given variety and maturity stage according to their commercial interests.

\section{Acknowledgements}

We are grateful to the Coordenação de Aperfeiçoamento de Pessoal de Nivel Superior (CAPES) for the scholarship. The authors thank all who contributed directly or indirectly to this study.

\section{References}

Almeida, M. M. B., Sousa, P. H. M., Arriaga, Â. M. C., Prado, G. M., Magalhães, C. E. C., Maia, G. A., \& de Lemos, T. L. G. (2011). Bioactive compounds and antioxidant activity of fresh exotic fruits from northeastern Brazil. Food Research International, 44(7), 21552159. http://dx.doi.org/10.1016/j.foodres.2011.03.051.

Alves, R. E., Filgueiras, H. A. C., Moura, C. F. H., Araújo, N. C. C., \& Almeida, A. S. (2002). Camu-Camu (Myrciaria dubia Mc Vaugh): A rich natural source of vitamin C. Proceedings of the Interamerican Society for Tropical Horticulture, 46, 11-13.

Association of Official Analytical Chemists - AOAC. (1984). Official methods of analysis of the Association of Official Analytical Chemists (14th ed., Method 43.065). Arlington: AOAC.

Assunção, R. B., \& Mercadante, A. Z. (2003). Carotenoids and ascorbic acid from cashew apple (Anacardium occidentale L.): Variety and geographic effects. Food Chemistry, 81(4), 495-502. http://dx.doi. org/10.1016/S0308-8146(02)00477-6.

Azevedo-Meleiro, C. H., \& Rodriguez-Amaya, D. B. (2004). Confirmation of the identity of the carotenoids of tropical fruits by HPLC-DAD 
and HPLC-MS. Journal of Food Composition and Analysis, 17(3-4), 385-396. http://dx.doi.org/10.1016/j.jfca.2004.02.004.

Brand-Williams, W., Cuvelier, M. E., \& Berset, C. (1995). Use of a free radical method to evaluate antioxidant activity. LebensmittelWissenschaft + Technologie, 28(1), 25-30. http://dx.doi.org/10.1016/ S0023-6438(95)80008-5.

Chen, Z., Bertin, R., \& Froldi, G. (2013). EC estimation of antioxidant activity in DPPH assay using several statistical programs. Food Chemistry, 138(1), 414-420. PMid:23265506. http://dx.doi.org/10.1016/j. foodchem.2012.11.001.

Chirinos, R., Galarza, J., Betalleluz-Pallardel, I., Pedreschi, R., \& Campos, D. (2010). Antioxidant compounds and antioxidant capacity of Peruvian camu camu (Myrciaria dubia (H.B.K.) McVaugh) fruit at different maturity stages. Food Chemistry, 120(4), 1019-1024. http:// dx.doi.org/10.1016/j.foodchem.2009.11.041.

Correa, S. I., Zamudio, L. B., Solís, V. S., \& Cruz, C. O. (2011). Vitamin C content in fruits of camu camu Myrciaria dubia (H.B.K) Mc Vaugh, in four states of maturation, coming from the Collection of Germoplasma of the INIA Loreto, Peru. Scientia Agropecuaria, 2(3), 123-130. http://dx.doi.org/10.17268/sci.agropecu.2011.03.01.

Delva, L., \& Goodrich-Schneider, R. (2013). Antioxidant activity and antimicrobial properties of phenolic extracts from acerola (Malpighia emarginata DC) fruit. International Journal of Food Science \& Technology, 48(5), 1048-1056. https://doi.org/10.1111/ijfs.12061.

Fu, X., Feng, C., Wang, C., Yin, X., Lu, P., Grierson, D., Xu, C., \& Chen, K. (2014). Involvement of multiple phytoene synthase genes in tissue- and cultivar-specific accumulation of carotenoids in loquat. Journal of Experimental Botany, 65(16), 4679-4689. PMid:24935622. http://dx.doi.org/10.1093/jxb/eru257.

Fuleki, T., \& Francis, F. J. (1968). Quantitative methods for anthocyanins. Journal of Food Science, 33(7), 266-274. http://dx.doi. org/10.1111/j.1365-2621.1968.tb01365.x.

Georgé, S., Brat, P., Alter, P., \& Amiot, M. J. (2005). Rapid determination of polyphenols and vitamin C in plant-derived products. Journal of Agricultural and Food Chemistry, 53(5), 1370-1373. PMid:15740008. http://dx.doi.org/10.1021/jf048396b.

Huber, L. S., \& Rodriguez-Amaya, D. B. (2008). Flavonóis e flavonas: fontes brasileiras e fatores que influenciam a composição em alimentos. Alimentos e Nutrição, 19, 97-108. Retrieved from http://serv-bib.fcfar. unesp.br/seer/index.php/alimentos/article/view/205/210

Jaakola, L., Määttä, K., Pirttilä, A. M., Törrönen, R., Kärenlampi, S., \& Hohtola, A. (2002). Expression of Genes Involved in Anthocyanin Biosynthesis in Relation to Anthocyanin, Proanthocyanidin, and Flavonol Levels during Bilberry Fruit Development. Plant Physiology, 130(2), 729-739. PMid:12376640. http://dx.doi.org/10.1104/pp.006957.

Justi, K. C., Visentainer, J. V., Souza, N. E., \& Matsushita, M. (2000). Nutritional composition and vitamin C stability in stored camu-camu (Myrciaria dubia) pulp. Archivos Latinoamericanos de Nutricion, 50(4), 405-408. PMid:11464674.

Lees, D., \& Francis, F. (1972). Standardization of pigment analyses in cranberries. HortScience, 7, 83-84. Retrieved from http://scholar. google.com/scholar?hl=en\&btnG=Search\&q=intitle:Standardizat ion+of+pigment+analyses+in+cranberries $\# 0$

Manach, C., Scalbert, A., Morand, C., Rémésy, C., \& Jiménez, L. (2004). Polyphenols: Food sources and bioavailability. The American Journal of Clinical Nutrition, 79(5), 727-747. PMid:15113710.

Matta, V. M., Moretti, R. H., \& Cabral, L. M. C. (2004). Microfiltration and reverse osmosis for clarification and concentration of acerola juice. Journal of Food Engineering, 61(3), 477-482. http://dx.doi. org/10.1016/S0260-8774(03)00154-7.

Meda, A., Lamien, C. E., Romito, M., Millogo, J., \& Nacoulma, O. G. (2005). Determination of the total phenolic, flavonoid and proline contents in Burkina Fasan honey, as well as their radical scavenging activity. Food Chemistry, 91(3), 571-577. http://dx.doi.org/10.1016/j. foodchem.2004.10.006.

Reynertson, K. A., Yang, H., Jiang, B., Basile, M. J., \& Kennelly, E. J. (2008). Quantitative analysis of antiradical phenolic constituents from fourteen edible Myrtaceae fruits. Food Chemistry, 109(4), 883-890. PMid:21340048. http://dx.doi.org/10.1016/j.foodchem.2008.01.021.

Rice-Evans, C. A., Miller, N. J., \& Paganga, G. (1996). Structureantioxidant activity relationships of flavonoids and phenolic acids. Free Radical Biology \& Medicine, 20(7), 933-956. PMid:8743980. http://dx.doi.org/10.1016/0891-5849(95)02227-9.

Rodriguez, D. (2001). A guide to carotenoid analysis in foods. Washington: International Life Sciences Institute. Retrieved from http://beautyreview.nl/wp-content/uploads/2014/11/A-guide-to-carotenoidanalysis-in-foods.pdf

Rufino, M., Alves, R. E., Brito, E. S., Pérez-Jiménez, J., Saura-Calixto, F., \& Mancini-Filho, J. (2010). Bioactive compounds and antioxidant capacities of 18 non-traditional tropical fruits from Brazil. Food Chemistry, 121(4), 996-1002. http://dx.doi.org/10.1016/j. foodchem.2010.01.037.

Rutz, J. K., Voss, G. B., \& Zambiazi, R. C. (2012). Influence of the degree of maturity on the bioactive compounds in blackberry (Rubus spp.) cv. Tupy. Food and Nutrition Sciences, 3(10), 1453-1460. http://dx.doi. org/10.4236/fns.2012.310189.

Singleton, V. L., \& Rossi, J. A. (1965). Colorimetry of total phenolic with phosphomolybdic-phosphotungstic acid reagents. American Journal of Enology and Viticulture, 16, 144-158.

Statsoft Inc. (2004). Statistica: data analysis software system. Version 7. Tulsa: Statsoft. Retrieved from www.statsoft.com

Villanueva-Tiburcio, J. E., Condezo-Hoyos, L. A., \& Asquieri, E. R. (2010). Antocianinas, ácido ascórbico, polifenoles totales y actividad antioxidante, en la cáscara de camu-camu (Myrciaria dubia (H.B.K) McVaugh). Food Science and Technology, 30, 151-160. http://dx.doi. org/10.1590/S0101-20612010000500023.

Wink, M. (2004). Phytochemical diversity of secondary metabolites. In R. M. Goodman. Encyclopedia of Plant and Crop Science (pp. 915-919). New York: Marcel Dekker.

Yazawa, K., Suga, K., Honma, A., Shirosaki, M., \& Koyama, T. (2011). Anti-inflammatory effects of seeds of the tropical fruit camu-camu (Myrciaria dubia). Journal of Nutritional Science and Vitaminology, 57(1), 104-107. PMid:21512298. http://dx.doi.org/10.3177/jnsv.57.104.

Yuyama, K. A. (2011). Cultura de camu-camu no Brasil. Revista Brasileira de Fruticultura, 33(2), 335-690. http://dx.doi.org/10.1590/ S0100-29452011000200001.

Zanatta, C. F., \& Mercadante, A. Z. (2007). Carotenoid composition from the Brazilian tropical fruit camu-camu (Myrciaria dubia). Food Chemistry, 10(4), 1526-1532. http://dx.doi.org/10.1016/j. foodchem.2006.04.004.

Zanatta, C. F., Cuevas, E., Bobbio, F. O., Winterhalter, P., \& Mercadante, A. Z. (2005). Determination of anthocyanins from camu-camu (Myrciaria dubia) by HPLC-PDA, HPLC-MS, and NMR. Journal of Agricultural and Food Chemistry, 53(24), 9531-9535. PMid:16302773. http://dx.doi.org/10.1021/jf051357v. 